\title{
ANALISIS REGRESI TEMPORAL DARI KINERJA MESIN PEMBUAT ES BERTENAGA SURYASEBAGAI FUNGSI DARI RADIASI MATAHARI DAN SUHU UDARA DI PESISIR LAMPUNG SELATAN
}

\section{TEMPORAL REGRESSION ANALISYS OF SOLAR-POWERED ICE MAKER PERFORMANCE AS THE FUNCTION OF SOLAR RADIATION AND AIR TEMPERATURE IN SOUTH LAMPUNG COASTAL REGION}

\author{
Putri Wullandari \& Arif Rahman Hakim \\ Loka Riset Mekanisasi Pengolahan Hasil Perikanan, Bantul \\ e-mail : utides@gmail.com
}

Diterima tanggal: 24 Mei 2018 ; diterima setelah perbaikan: 6 Juni 2021 ; Disetujui tanggal: 6 Juni 2021

\begin{abstract}
ABSTRAK
Artikel ilmiah ini membahas hasil evaluasi kinerja mesin pembuat es bertenaga surya di TPI Kramat, pesisir Lampung Selatan. Mesin pembuat es yang dievaluasi adalah memiliki kapasitas 105-120 kg es/jam, 9 panel surya 200 WP yang dipasang pada frame yang berukuran $43 \mathrm{~m}$ x $30 \mathrm{~m}$ x $27 \mathrm{~m}$, dan baterai 200 AH sebanyak 4 buah. Evaluasi kinerja dilakukan selama November 2016 hingga Februari 2017. Hasil penelitian menunjukkan bahwa terdapat hubungan antara intensitas radiasi matahari $\left(\mathrm{x}_{1}\right)$ dan suhu udara harian $\left(\mathrm{x}_{2}\right)$ dengan produksi es (y) di TPI Kramat, Lampung Selatan. Pada bulan November 2016, peralihan musim kemarau ke musim penghujan, hubungan ini dinyatakan dengan persamaan regresi $\mathrm{y}=93,2+0,04 \mathrm{x} 1-3,28 \mathrm{x}_{2}$. Pada Desember 2016, awal musim penghujan, hubungan ini dinyatakan dengan persamaan $\mathrm{y}=8,42+0,006 \mathrm{x} 1+0,004 \mathrm{x}_{2}$. Pada Januari 2017, puncak musim penghujan, hubungan ini dinyatakan dengan persamaan $y=-6,608-0,004$ $\mathrm{x} 1+0,752 \mathrm{x}_{2}$. Pada Februari 2017, akhir dari musim penghujan, hubungan ini dinyatakan dengan persamaan y $=19,16+0,003 \times 1-0,289 \times 2$. Produksi es pada musim penghujan ada indikasi penurunan namun masih bisa mencukupi kebutuhan nelayan.
\end{abstract}

Kata kunci : Kinerja mesin pembuat es, tenaga surya, radiasi matahari, suhu udara, musim kemarau, musim penghujan.

\begin{abstract}
This scientific article is an evaluation result of the performance test of solar-powered ice machine in Kramat's Fish Auction, South Lampung coastal region. The ice maker machine that has been evaluated have a capacity of 105-120 kg ice /hour, 9 solar panels (200 WP) mounted on a square frames (43 m x $30 \mathrm{~m} \times 27 \mathrm{~m}$ ), and 4 batteries 200 AH each. Performance tests were conducted at TPI Kramat, South Lampung coastal region during November 2016 until February 2017. The results showed that there was a functional association of the intensity of solar radiation $\left(x_{1}\right)$ and daily air temperature $(x 2)$ to the ice's production. In November 2016, transitional from dry to wet season, this relationship was expressed by the regression equation $y=93.2+0.04 \times 1-3.28 \times 2$. In December 2016, beginning of wet season, this relationship is expressed by the regression equation $y=8.42$ $+0.006 x 1+0.004 x_{2}$. In January 2017, peak of wet season, this relationship was expressed by the regression equation $y=-6,608-0,004 x 1+0,752 x_{2}$. In February 2017, end of wet season, this relationship was expressed by the regression equation $y=19,16+0,003 \times 1-0,289 x_{2}$. There is an indication of ice production decrease during wet season, but it is enough fulfilling for fisherman demand.
\end{abstract}

Keywords: Ice maker performance, solar power, solar radiation, air temperature, dry season, wet season. 


\section{PENDAHULUAN}

Konsumsi energi dunia yang semakin meningkat menciptakan kebutuhan mendesak untuk menemukan cara baru untuk menggunakan sumber energi dengan cara yang lebih efisien dan lebih rasional, diperkirakan konsumsi energi global akan meningkat sekitar 71\% dari 2003 sampai 2030 (Sarbu \& Adam, 2011; Sarbu \& Sebarchievici, 2013).

Siklus kompresi berbasis uap ditenagai dengan listrik, mengkonsumsi energi dalam jumlah besar, yang meningkatkan konsumsi bahan bakar fosil secara signifikan. Salah satu contoh keterbatasan bahan bakar fosil yaitu produksi minyak bumi nasional sudah menurun sehiingga untuk memenuhi kebutuhan dalam negeri saja kita harus melakukan impor (EIA, 2006). Oleh karena itu perlu dicari pengganti bahan bakar fossil, yaitu dengan memanfaatkan energi baru terbarukan. Energi terbarukan merupakan bentuk energi yang tidak dapat habis atau memiliki kemampuan alami untuk memperbarui dirinya sendiri (Sarbu \& Sebarhievici). Sumber energi terbarukan antara lain yaitu angin, ombak, matahari, biomassa, tenaga air, energi geotermal dan pasang surut (Hassan \& Mohamad, 2012, Fernandes et al., 2014).

Beberapa tahun terakhir, para ilmuwan dan peneliti banyak menaruh perhatian terhadap penggunaan energi matahari. Energi matahari merupakan hasil dari radiasi elektromagnetik yang dilepaskan oleh matahari dengan reaksi termonuklir yang muncul di dalam intinya. Total radiasi sinar matahari yang ditransmisikan ke bumi mencapai sekitar $1,74 \times 10^{17} \mathrm{~W}$, sedangkan keseluruhan konsumsi energi di bumi mencapai 1,84 x $1013 \mathrm{~W}$ (Solanki, 2013).

Refrigerator dan mesin pembuat es bertenaga listrik dan termal (panas) dapat digunakan untuk menghasilkan pendinginan. Ada dua macam sistem, yang pertama yaitu photovoltaic $(\mathrm{PV})$ berbasis sistem energi matahari, dimana energi matahari pertama-tama dirubah menjadi energi listrik kemudian digunakan untuk menghasilkan pendinginan, hampir sama dengan metode konvensional. Sistem yang kedua yaitu menggunakan energi panas matahari sebagai sumber untuk sistem refrigerasi absorbsi. Yang akan dibahas dalam tulisan ini yaitu mengenai sistem yang pertama.

Beberapa faktor yang mempengaruhi kerja panel surya antara lain panjang kabel listrik yang digunakan untuk menghubungkan panel surya dengan beban, kemiringan panel surya terhadap sudut datang cahaya matahari dan kondisi cuaca cerah atau mendung (tinggi atau rendahnya intensitas radiasi matahari). Agar efisiensi sel surya bisa tinggi maka photon yang berasal dari sinar matahari harus bisa diserap yang sebanyakbanyaknya, kemudian memperkecil refleksi dan rekombinasi serta memperbesar konduktivitas dari bahannya (Aditiyan, 2015).

Sel surya dapat beroperasi secara maksimal jika temperatur sel tetap normal pada $25^{\circ} \mathrm{C}$. Kenaikan temperatur lebih tinggi dari temperatur normal pada sel surya akan melemahkan tegangan (Voc). Radiasi matahari di bumi pada lokasi yang berbeda akan bervariabel dan sangat tergantung dengan keadaan spektrum matahari ke bumi. (Pahlevi, 2014). Tujuan penelitian ini yaitu untuk mengetahui hubungan antara intensitas radiasi matahari dan suhu udara harian dengan produksi es di TPI Kramat, pesisir Lampung Selatan.

\section{BAHAN DAN METODE}

\section{Bahan}

Bahan utama yang digunakan dalam penelitian ini adalah mesin pembuat es curah dan sistem photovoltaic. Mesin pembuat es curah memiliki spesifikasi sebagai berikut :

1. Kapasitas produksi mencapai $120 \mathrm{~kg}$ es/ hari

2. Menghasilkan es dalam bentuk flakes/ serut

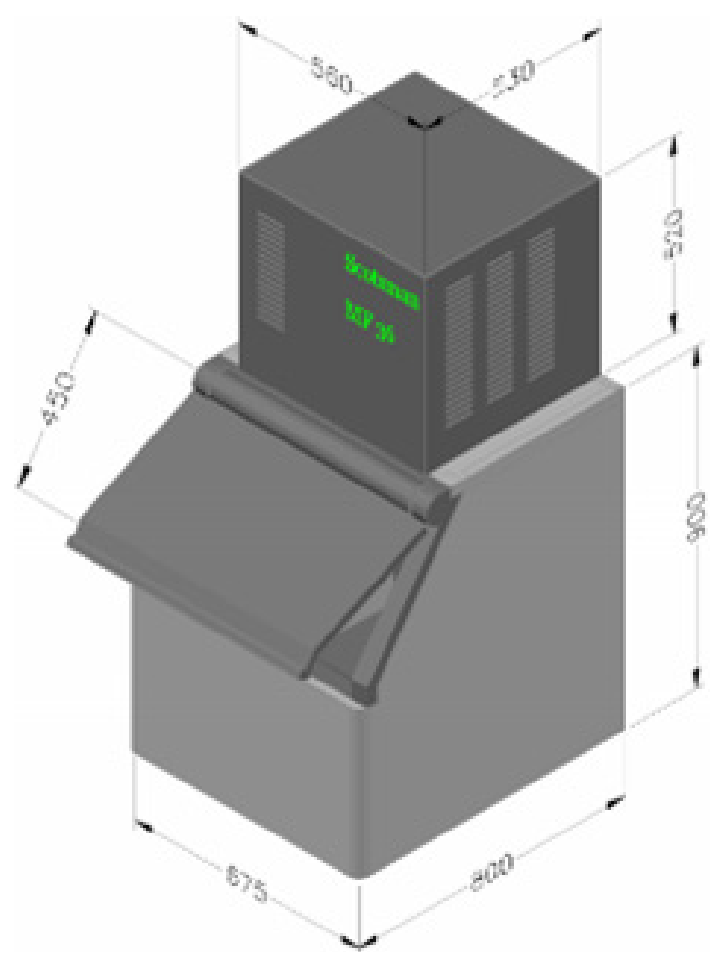

Gambar 1. Mesin pembuat es serut

Figure 1. Flakes ice maker machine Sumber : Dokumentasi pribadi 

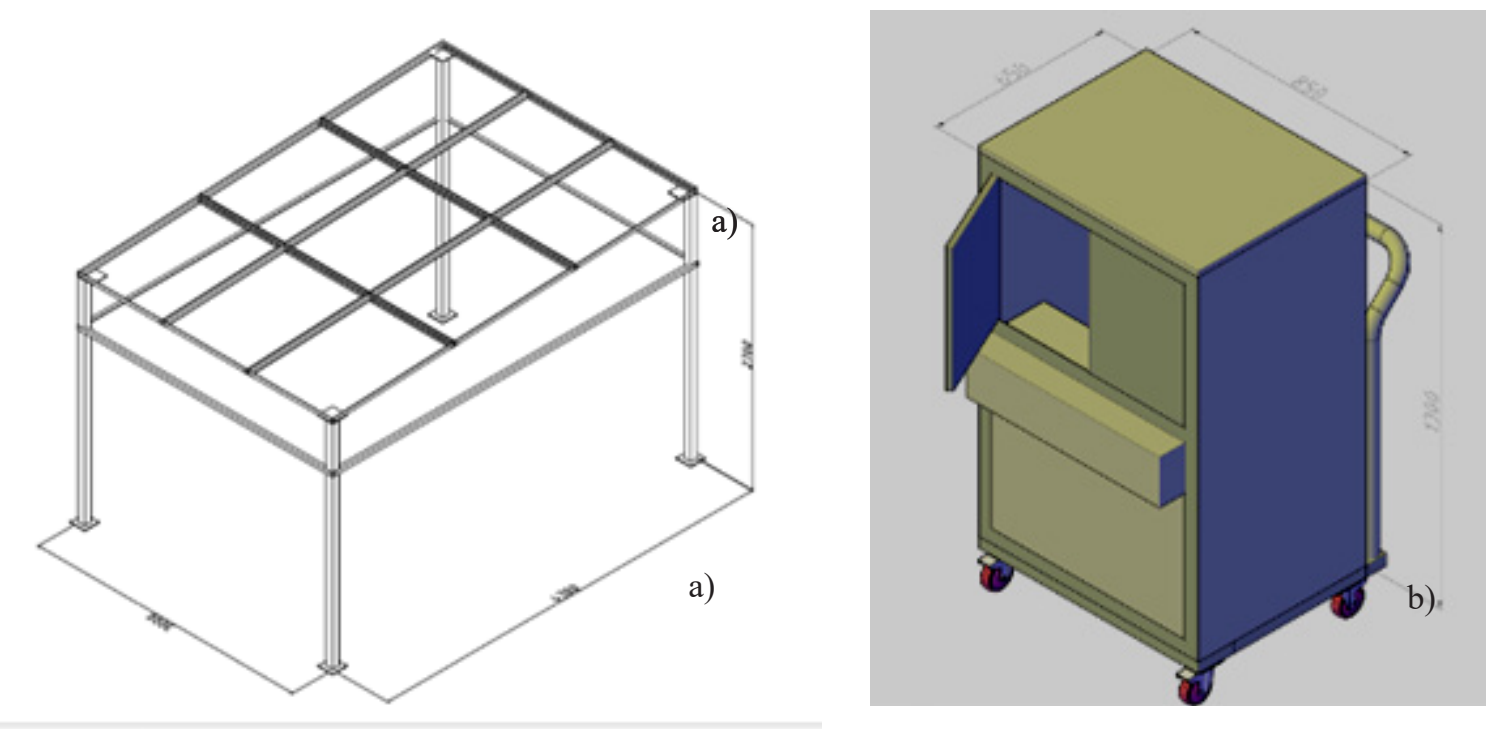

Gambar 2. (a) Frame panel surya, (b) wadah untuk menyimpan baterai dan inverter.

Figure 2. (a) solar panel's frame, (b) container to store the battery and the inverter. Sumber : Dokumentasi pribadi

3. Menggunakan sumber tenaga surya dan listrik

4. Es serut yang dihasilkan memiliki dimensi $2 \times 3 \times$ $3 \mathrm{~mm}$

5. Dimensi mesin pembuat es yaitu $680 \times 680 \times 1020$ $\mathrm{mm}$

Panel surya atau photovolatic panel berfungsi untuk mengubah sinar matahari menjadi energi listrik (Kumara, 2010). Sistem photovoltaic terdiri atas 9 buah panel surya berukuran 200 WP yang dipasang pada frame dengan ukuran $43 \mathrm{~m}$ x $30 \mathrm{~m}$ x $27 \mathrm{~m}$, dan baterai $200 \mathrm{AH}$ sebanyak 4 buah.
Alat

Peralatan yang digunakan untuk uji coba performansi yaitu luxmeter Lutron LX-107HA, tang ampere Sanwa Digital Clamp Meter DCM2000AD, laptop, stopwatch Alba, termometer 4 channel Lutron TM-946. Spesifikasi panel surya yang digunakan disajikan dalam Tabel 1.

\section{Metode Penelitian}

Metode penelitian disajikan pada Gambar 3. Penelitian ini merupakan bagian dari uji kinerja alat oleh pengguna, dengan uraian sebagai berikut: pertama-tama dirangkai mesin pembuat es dan panel surya, kemudian mesin pembuat es dan panel surya dioperasikan selama

Tabel 1. Spesifikasi panel surya

Table 1. Solar panel's spesification

\begin{tabular}{ll}
\hline Merek & $:$ ICA solar \\
Tipe panel surya & $:$ Polycrystalline \\
Daya Maksimum (Pmax) & $: 200 \mathrm{~W}$ \\
Tegangan Maksimum (Vmp) & $: 35.8 \mathrm{~V}$ \\
Arus Maksimum (Imp) & $: 5.59 \mathrm{~A}$ \\
Tegangan Sirkuit Terbuka (Voc ) & $: 44.85 \mathrm{~V}$ \\
Short Circuit Current (Isc) & $: 5.92 \mathrm{~A}$ \\
Nominal Operating Cell Temp. (NOCT) & $: 45^{\circ} \mathrm{C} \pm 2^{\circ} \mathrm{C}$ \\
Tegangan Sistem maksimum & $: 1000 \mathrm{VDC}$ \\
Maximum Series Fuse & $: 10 \mathrm{~A}$ \\
Untuk koneksi lapangan, gunakan minimum & tembaga No.12AWG \\
Kabel terisolasi minimal 90 $90^{\circ} \mathrm{C}$ & \\
Berat & $: 15.3 \mathrm{~kg}$ \\
Dimensi & $: 1320 \times 992 \times 40 \mathrm{~mm}$ \\
Kondisi tes standard & $:$ Temp. $25^{\circ} \mathrm{C}$ \\
& Air Mass $=1.5$ \\
& Irradiance $=1000 \mathrm{~W} / \mathrm{m} 2$
\end{tabular}

Analisis Regresi Temporal Dari Kinerja Mesin Pembuat Es Bertenaga Surya Sebagai Fungsi Dari Radiasi Matahari dan Suhu Udara di Pesisir Lampung Selatan - Putri Wullandari \& Arif Rahman Hakim 
4 bulan (pertengahan November 2016 sampai dengan Februari 2017) sambil dicatat data produksi esnya. November adalah puncak dari peralihan dari musim kemarau ke musim penghujan, sedangkan Desember hingga Februari adalah musim penghujan (Bramawanto \& Abida, 2017). Data intensitas radiasi matahari dan suhu udara harian diperoleh dari Badan Meteorologi, Klimatologi dan Geofisika Radin Inten II, Lampung Selatan. Analisis temporal, Analisis of Varians (ANOVA) dan pembangunan model hubungan regresi menggunakan Analysis Toolpak Plugin yang tersedia di Microsoft Excel (Junaidi, 2014; Iskandar et al., 2018). Variabel yang dianalisis secara statistik adalah: y sebagai produksi es, $\mathrm{x} 1$ sebagi intensitas radiasi matahari, dan $\mathrm{x} 2$ sebagai suhu udara lingkungan.

\section{Waktu dan tempat penelitian}

Lokasi penelitian diselenggarakan pada November 2016 - Februari 2017 di Tempat Pelelangan Ikan (TPI) Kramat, di Dusun Kramat, Desa Sumur, Kecamatan Ketapang, Kabupaten Lampung Selatan, Provinsi Lampung, lihat Gambar 4. TPI Kramat ini dipilih sebagai lokasi evaluasi kinerja alat karena suplai air tawar dan daya listrik di daerah ini sudah mencukupi, serta menjadi lokasi yang sering dikunjungi oleh nelayan dan pedagang ikan. Kebutuhan es di TPI Kramat pada kondisi normal mencapai 7 balok es, sedangkan pada saat musim panen bisa mencapai dua kali lipatnya.

Uji coba mesin pembuat es tenaga surya pada November 2016 dilakukan selama 10 hari, kemudian dilakukan selama 30 hari pada 30 hari. Sedangkan pada Januari dan Februari 2017 masing-masing dilakukan selama 28 hari. Pengolahan dan analisis data dilaksanakan di Loka Riset Mekanisasi Pengolahan Hasil Perikanan, Bantul, DIY Jogyakarta.

\section{HASIL DAN PEMBAHASAN}

.Tegangan dan arus listrik yang dihasilkan oleh sel surya dipengaruhi oleh dua variabel fisis, yaitu intensitas radiasi cahaya matahari dan suhu udara lingkungan (Adiyana \& Supriyono, 2015; Bramawanto et al., 2019). Intensitas radiasi cahaya matahari yang diterima sel surya sebanding dengan tegangan dan arus listrik yang dihasilkan oleh sel surya, sedangkan apabila suhu udara lingkungan semakin tinggi dengan intensitas radiasi cahaya matahari yang tetap, maka tegangan panel surya akan berkurang dan arus listrik yang dihasilkan akan bertambah (Suryana \& Ali, 2016). Semakin tinggi suhu lingkungan sekitar panel surya, daya listrik yang dihasilkan oleh panel surya semakin

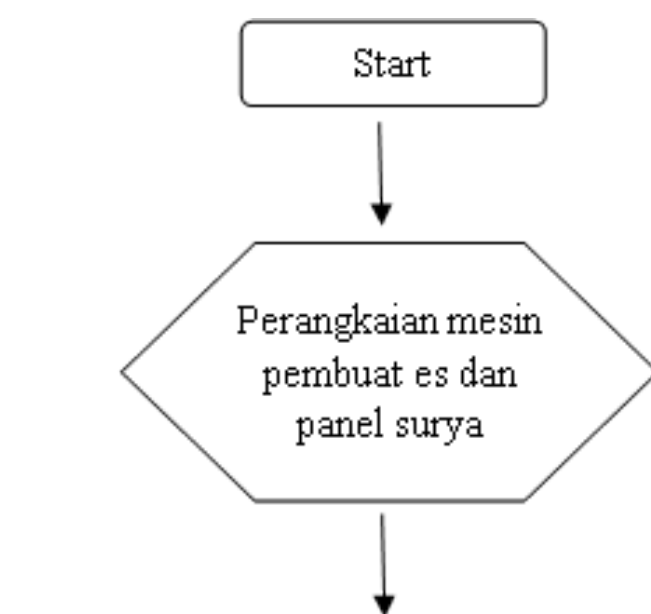

Pencatatan data produksi es selama 4 bulan (November 2016 - Februari 2017)
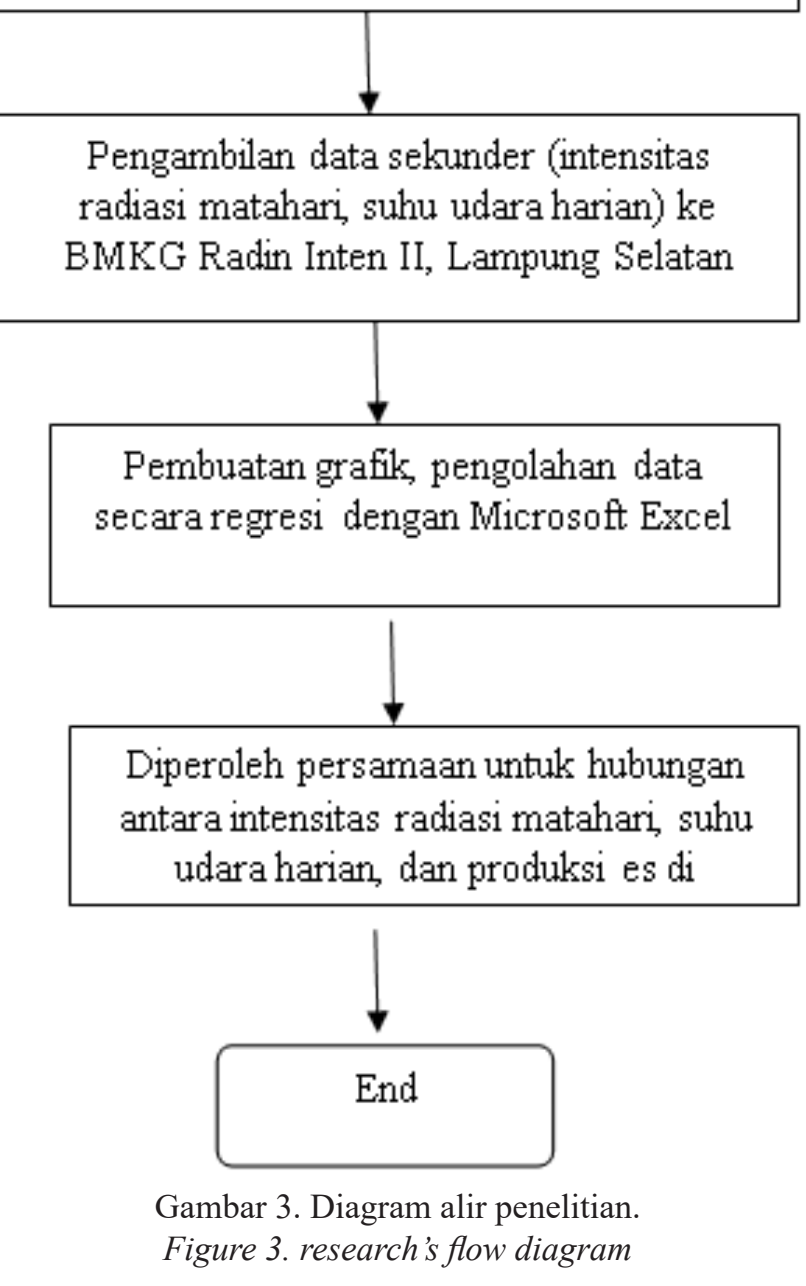

berkurang (Adiyana \& Supriyono, 2015; Bramawanto et al., 2019). Selain itu, radiasi elektromagnetik yang diserap oleh panel surya juga dapat menaikkan suhu sel-sel surya (Khwee, 2013).

Gambar 5 memperlihatkan bahwa produksi es (y) tertinggi, pada November 2016 sebagai periode 


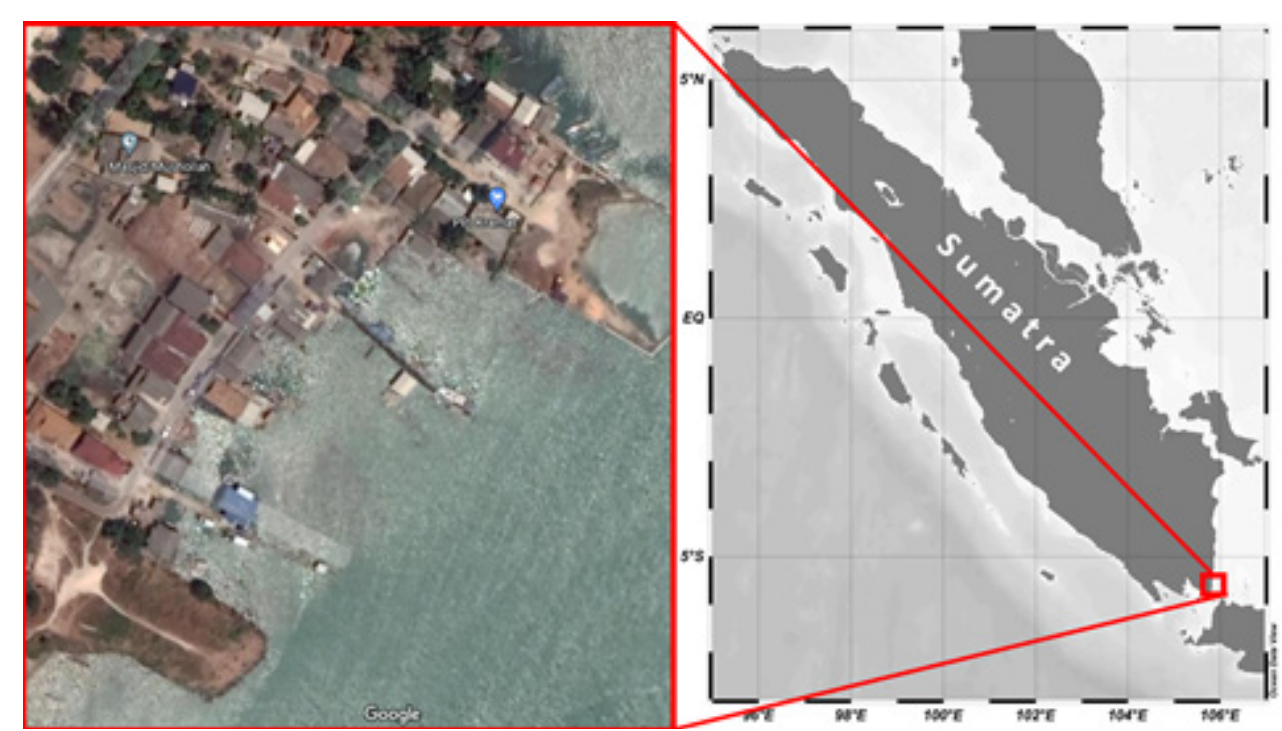

Gambar 4. Lokasi penelitian di Tempat Pelelangan Ikan (TPI) di kompleks Pelabuhan Pendaratan Ikan (PPI) Kramat, Kabupaten Lampung Selatan, Provinsi Lampung. (sumber: kiri: foto satelit dari google map; kanan: Pulau Sumatra dari Ocean Data View'Schlitzer, 2020).

Figure 4. The research has been conducted in Fish Auction Market which is part of the Fish Landing Port in Kramat, South Lampung Regency, Lampung Province. (Source: left: satellite photo from google map; right: Sumatra island from Ocean Data View'Schlitzer, 2020)

peralihan dari musim kemarau ke musim penghujan, 93,2+0,04 $\mathrm{x}_{1}-3,28 \mathrm{x} 2$. yaitu sebesar $37,89 \mathrm{~kg}$ yang dicapai saat intensitas radiasi matahari $\left(\mathrm{x}_{1}\right)$ bernilai sebesar 707,5 joule/ Uji coba mesin pembuat es tenaga surya pada $\mathrm{m} 2$ dan suhu udara lingkungan $\left(\mathrm{x}_{2}\right)$ sebesar $27,6^{\circ} \mathrm{C}$. Desember 2016 disajikan pada Gambar 6. Gambar Produksi es terendah yaitu sebesar $12 \mathrm{~kg}$ yang dicapai tersebut memperlihatkan bahwa produksi es (y), pada saat intensitas radiasi matahari bernilai sebesar 327,7 awal musim penghujan, tertinggi yaitu sebesar 17,33 joule $/ \mathrm{m}^{2}$ dan suhu udara lingkungan sebesar $25,6^{\circ} \mathrm{C}$. $\mathrm{kg}$ yang dicapai saat intensitas radiasi matahari (x1) Statistik ANOVA menunjukkan bahwa nilai $\mathrm{F}$ hitung bernilai sebesar 528,8 joule $/ \mathrm{m}^{2}$ dan suhu udara harian 0,669 dengan nilai signifikansi (P value) sebesar 0,542. $\left(\mathrm{x}_{2}\right)$ sebesar $27,3^{\circ} \mathrm{C}$. Produksi es terendah yaitu sebesar Persamaan model regresi yang diperoleh adalah $\mathrm{y}=7,467 \mathrm{~kg}$ yang dicapai saat intensitas radiasi matahari

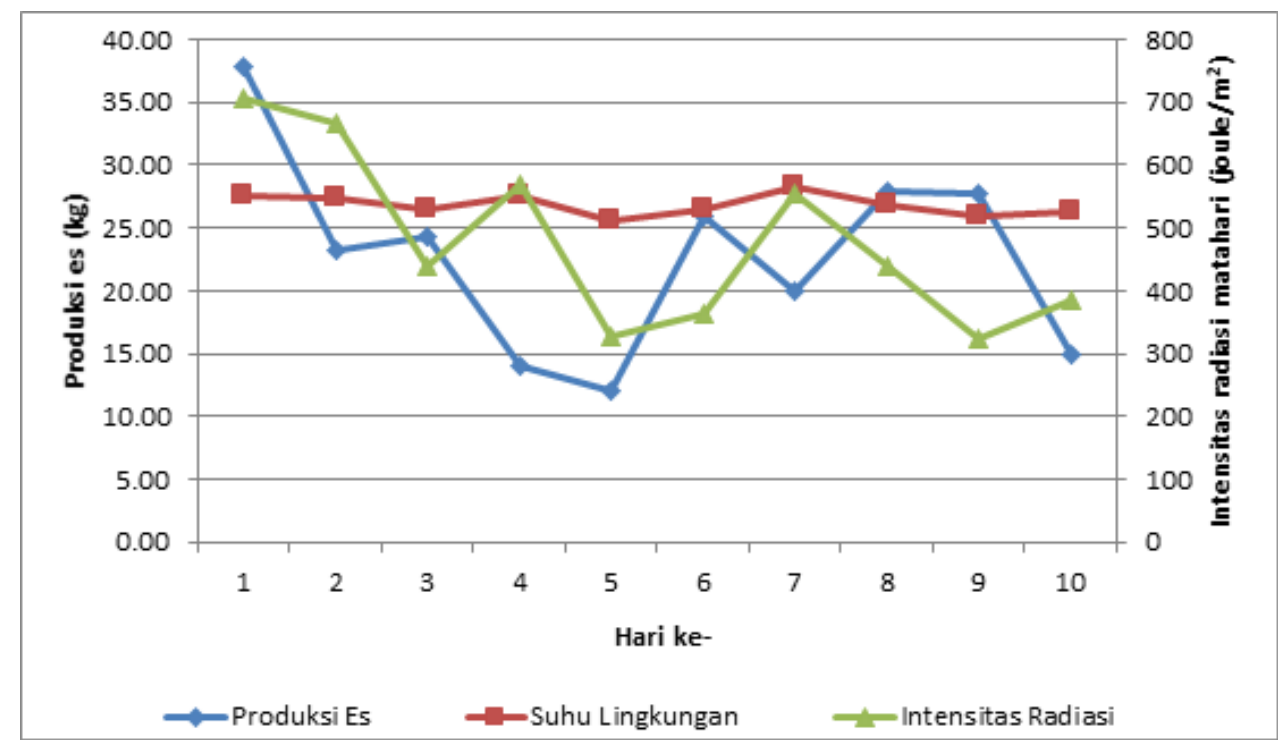

Gambar 5. Hasil produksi es, intensitas radiasi matahari, dan suhu udara rata-rata harian lingkungan pada November 2016.

Figure 5. Ice production, intensity of solar radiation, and average daily air temperature during November 2016. Sumber: Hasil pengukuran 
bernilai sebesar 472,9 joule $/ \mathrm{m}^{2}$ dan suhu udara harian sebesar $26,8^{\circ} \mathrm{C}$. Statistik ANOVA menunjukkan bahwa nilai $\mathrm{F}$ hitung 3,622 dengan nilai signifikansi (P value) sebesar 0,04 . Taraf signifikansi atau nyata $(5 \%)>\mathrm{P}$ value $(0,04)$, maka dapat diinterpretasikan bahwa intensitas radiasi matahari dan suhu udara harian mempengaruhi produksi es di bulan Desember 2016 (Junaidi, 2014). Persamaan regresi yang diperoleh adalah $\mathrm{y}=8,42+0,006 \mathrm{x}_{1}+0,004 \mathrm{x}_{2}$.

Uji coba mesin pembuat es tenaga surya pada bulan Januari 2017 disajikan pada Gambar 7. Gambar tersebut memperlihatkan bahwa produksi es (y) tertinggi pada puncak musim penghujan 2017 yaitu sebesar 14,857 $\mathrm{kg}$ yang dicapai saat intensitas radiasi matahari (x1) bernilai sebesar 603,2 joule $/ \mathrm{m}^{2}$ dan suhu udara harian (x2) sebesar $27,7^{\circ} \mathrm{C}$. Produksi es terendah yaitu sebesar $8 \mathrm{~kg}$ yang dicapai saat intensitas radiasi matahari bernilai sebesar 275,6 joule $/ \mathrm{m}^{2}$ dan suhu udara harian sebesar $24,6^{\circ} \mathrm{C}$. Statistik ANOVA menunjukkan bahwa nilai $\mathrm{F}$ hitung 1,004 dengan nilai signifikansi (P value) sebesar 0,38 . Persamaan regresi yang didapat adalah y $=-6,608-0,004 x_{1}+0,752 x_{2}$.

Gambar 8 memperlihatkan bahwa produksi es tertinggi (y) pada bulan Februari 2017, sebagai representasi akhir dari musim penghujan, yakni sebesar 19,2 kg yang dicapai saat intensitas radiasi matahari (x1) bernilai sebesar 674 joule $/ \mathrm{m}^{2}$ dan suhu udara harian $\left(\mathrm{x}_{2}\right)$ sebesar $27,3^{\circ} \mathrm{C}$. Produksi es terendah yaitu sebesar $9 \mathrm{~kg}$ yang dicapai saat intensitas radiasi matahari bernilai sebesar 331,4 joule $/ \mathrm{m}^{2}$ dan suhu udara harian sebesar $25,6^{\circ} \mathrm{C}$. Statistik ANOVA menunjukkan bahwa nilai $\mathrm{F}$ hitung 0,186 dengan nilai signifikansi (P value) sebesar 0,831 . Persamaan regresi yang berhasil dikonstruksi adalah y $=19,16+0,003 \mathrm{x}_{1}-0,289 \times 2$.

Hasil observasi dari November 2016 sampai dengan Februari 2017, intensitas radiasi matahari tertinggi yaitu pada periode awal musim penghujan yakni pada 20 Desember 2016 sebesar 815,5 joule $/ \mathrm{m}^{2}$. Intensitas radiasi matahari terendah terjadi pada periode akhir dari musim penghujan, yakni pada tanggal 21 Februari 2017 sebesar 175 joule/m2. Suhu udara lingkungan dalam periode 4 bulan ujicoba alat, di wilayah pesisir Lampung Selatan, khususnya Kalianda, berkisar dalam rentang $24,6^{\circ} \mathrm{C}$ sampai dengan $28,9^{\circ} \mathrm{C}$. Wilayah pesisir Lampung Selatan merupakan wilayah perbatasan antara Laut Jawa, Selat Karimata dan Selat Sunda, sehingga suhu udara lingkungannya juga seperti suhu laut di wilayah tersebut yang sangat dipengaruhi oleh angin monsun (Siregar et al., 2017; Heryati et al., 2018). Angin monsun tersebut berkorelasi dengan musim penghujan yang umumnya terjadi antara Desember hingga Februari, sedangkan musim kemarau terjadi pada Juni hingga Agustus. Musim peralihan dari kemarau ke penghujan terjadi pada Maret hingga Mei, dan sebaliknya peralihan musim penghujan ke kemarau terjadi pada September hingga November (Sagala et al., 2014).

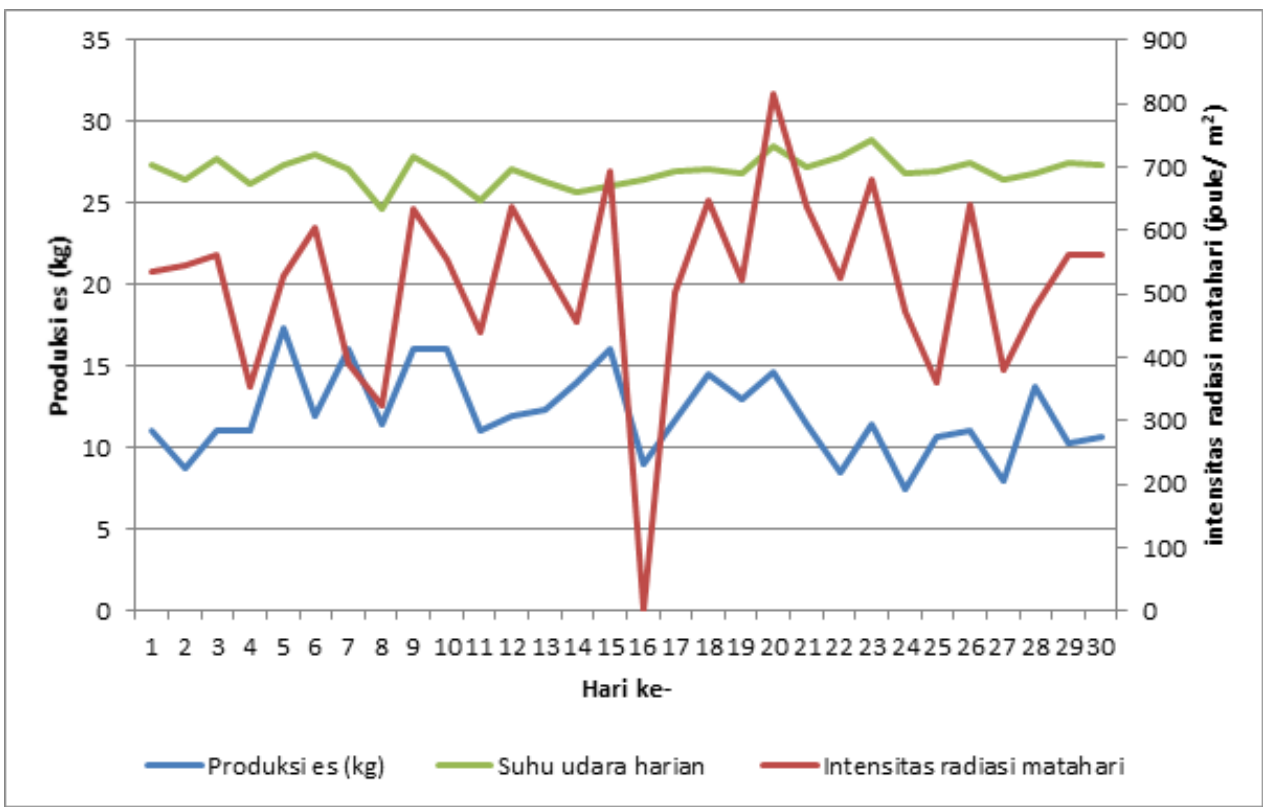

Gambar 6. Hasil produksi es, intensitas radiasi matahari, dan suhu udara rata-rata harian pada Desember 2016 Figure 6. Ice production, intensity of solar radiation, and average daily air temperature during December 2016 Sumber: Hasil pengukuran 


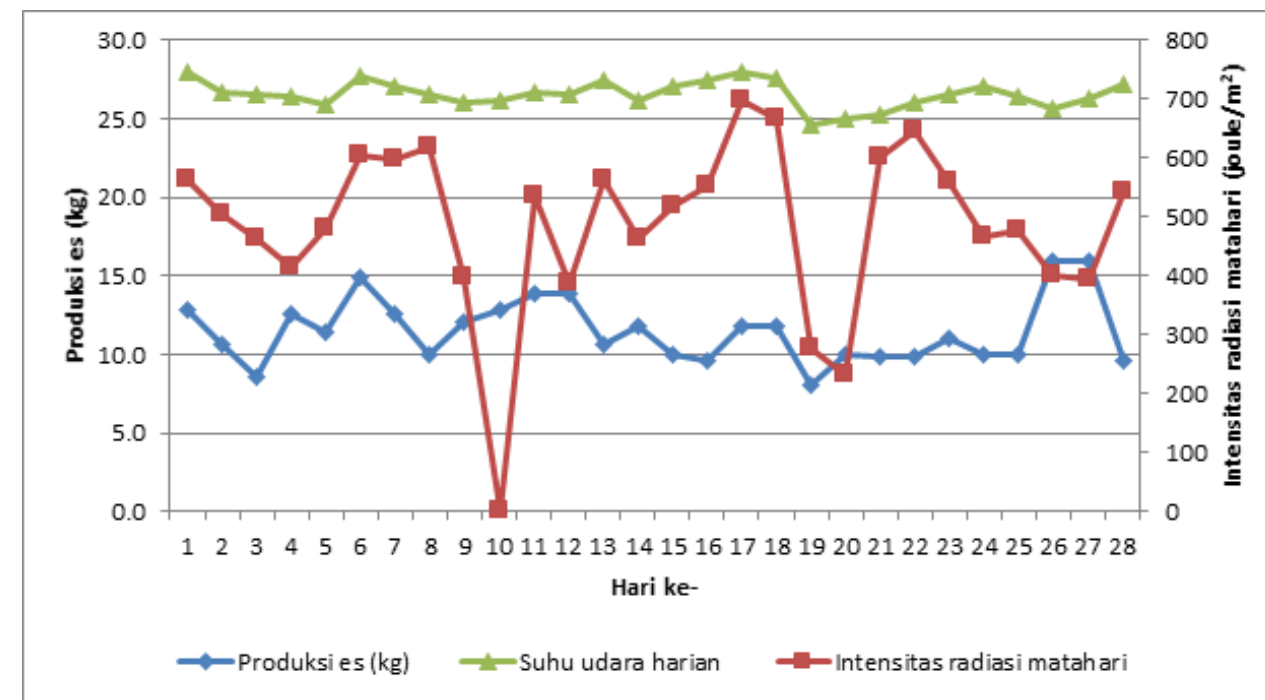

Gambar 7. Hasil produksi es, intensitas radiasi matahari, dan suhu udara rata-rata harian pada bulan Januari 2017

Figure 7. Ice production, intensity of solar radiation, and average daily air temperature during January 2017 Sumber: Hasil pengukuran

Produksi es tertinggi selama bulan November 2016 sampai dengan Februari 2017 dicapai pada November 2016 (akhir peralihan musim kemarau menuju musim penghujan) yaitu sebesar $37,89 \mathrm{~kg}$, sedangkan produksi es terendah dicapai pada Januari 2017 (puncak musim penghujan) yaitu sebesar $8 \mathrm{~kg}$. Secara umum, produksi es pada musim penghujan memang mengalami penurunan kinerja karena intensitas radiasi matahari tertahan oleh banyaknya awan, namun suhu udara lingkungan masih sangat mendukung. Berdasarkan hasil analisis ini maka bisa diduga bahwa pada musim kemarau mesin pembuat es akan dapat jauh lebih optimal lagi bekerja memproduksi es.

Berdasarkan observasi di lingkungan sekitar TPI Kramat, potensi menurunnya kinerja mesin pembuat es dalam waktu jangka panjang, diduga bisa disebabkan oleh air baku yang digunakan untuk membuat es merupakan air payau. Air payau adalah campuran antara air tawar dan air laut. Ciri-ciri fisik air payau

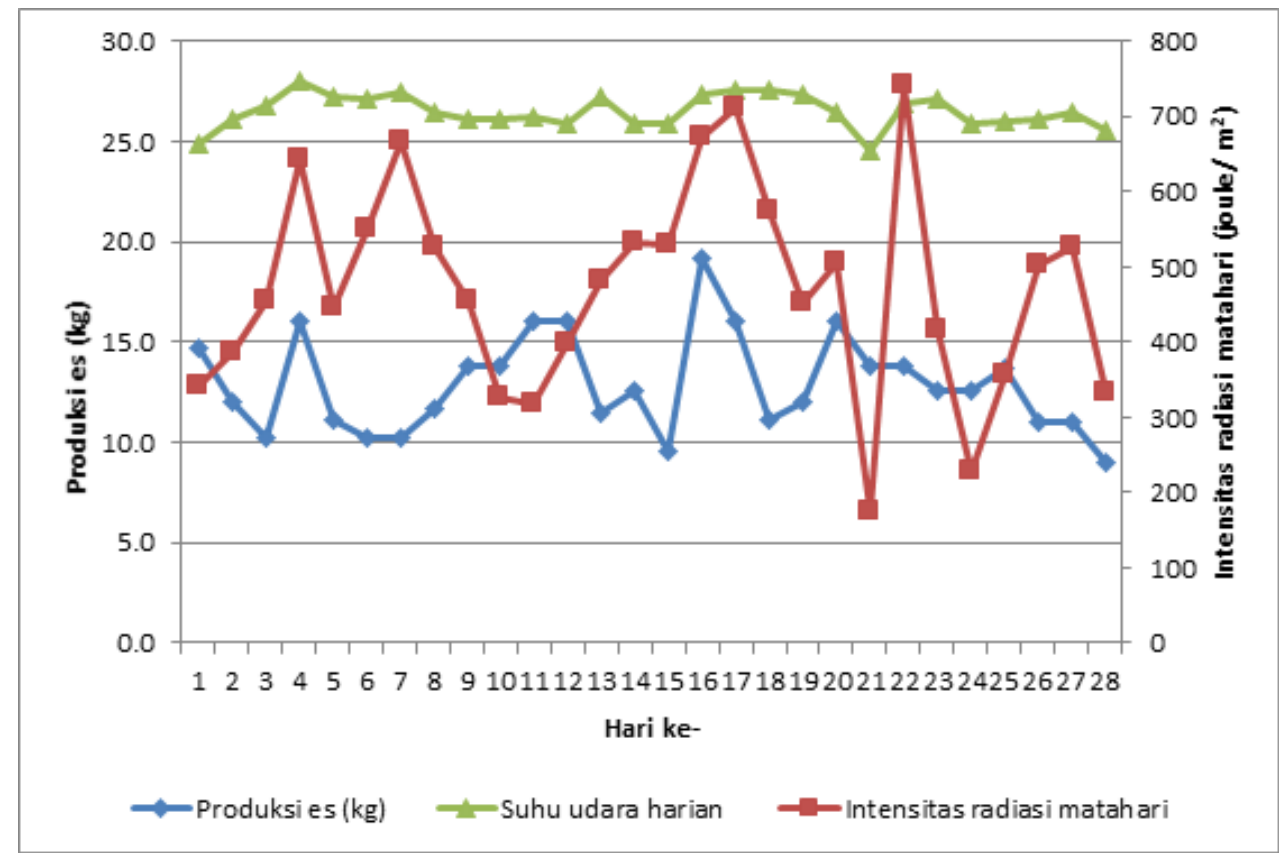

Gambar 8. Hasil produksi es, intensitas radiasi matahari, dan suhu udara rata-rata harian pada Februari 2017

Figure 8. Ice production, intensity of solar radiation, and average daily air temperature during February 2017 Sumber: Hasil pengukuran 
adalah sebagai berikut: berwarna coklat kehitaman, mengandung kadar garam lebih besar dibandingkan air tawar (Putra et al., 2018). Namun hal ini perlu dilakukan pengamatan yang kontinyu dalam jangka waktu yang panjang.

Penggunaan air payau secara terus-menerus dapat merusak komponen di dalam mesin pembuat es, karena spesifikasi mesin pembuat es ini diperuntukkan untuk membuat air tawar menjadi es. Sesuai dengan Keputusan Kepala Badan Karantina Ikan, Pengendalian Mutu, dan Keamanan Hasil Perikanan nomor 63/KEPBKIPM/2016 tentang Petunjuk Teknis Pengendalian Air dan Es untuk Penanganan dan Pengolahan Hasil Perikanan, es adalah air yang telah mengalami pembekuan dan berasal dari air minum dan digunakan untuk pengolahan, penanganan, dan distribusi hasil perikanan.

\section{KESIMPULAN DAN SARAN}

Terdapat hubungan nyata antara intensitas radiasi matahari, suhu udara harian, dan produksi es di Kramat, Lampung Selatan. Intensitas radiasi matahari yang menurun pada musim penghujan masih bisa diimbangi oleh suhu udara lingkungan yang menyebabkan kinerja mesin pembuat es bisa bekerja dengan baik. Mesin pembuat es bertenaga surya di TPI Kramat, Lampung Selatan selama November 2016 sampai dengan Februari 2017 dapat optimal bekerja dengan baik, pada musim peralihan dan penghujan, sehingga dirasakan cukup bermanfaat bagi para nelayan dan kelompok nelayan karena dapat membantu penyediaan es untuk pengawetan ikan segar.

\section{UCAPAN TERIMA KASIH}

Terdapat hubungan nyata antara intensitas radiasi matahari, suhu udara harian, dan produksi es di Kramat, Lampung Selatan. Intensitas radiasi matahari yang menurun pada musim penghujan masih bisa diimbangi oleh suhu udara lingkungan yang menyebabkan kinerja mesin pembuat es bisa bekerja dengan baik. Mesin pembuat es bertenaga surya di TPI Kramat, Lampung Selatan selama November 2016 sampai dengan Februari 2017 dapat optimal bekerja dengan baik, pada musim peralihan dan penghujan, sehingga dirasakan cukup bermanfaat bagi para nelayan dan kelompok nelayan karena dapat membantu penyediaan es untuk pengawetan ikan segar..

\section{DAFTAR PUSTAKA}

Adityan, N. (2015). Karakterisasi panel surya model SR-156P-100 berdasarkan intensitas cahaya matahari. Skripsi. Jurusan Teknik Elektro, Fakultas Teknik, Universitas Lampung.

Adiyana, K., \& Supriyono. E. (2015). Efisiensi Daya Listrik Dan Kondisi Oksigen Terlarut Pada Pemeliharaan Postlarva Udang Vaname Litopenaeus Vannamei Menggunakan Sumber Energi Surya. J. Kelautan Nasional, 10(1), 3341.

Badan Karantina Ikan, Pengendalian Mutu, dan Keamanan Hasil Perikanan. (2016). Keputusan Kepala Badan Karantina Ikan, Pengendalian Mutu, dan Keamanan Hasil Perikanan nomor 63/KEP-BKIPM/2016 tentang Petunjuk Teknis Pengendalian Air dan Es untuk Penanganan dan Pengolahan Hasil Perikanan.

Bramawanto, R., Triwibowo, H., \& Abida, R. F. (2019). Pemanfaatan Teknologi Mikrokontroler Untuk Pengukuran Evaporasi dan Suhu Pada Produksi Garam. J. Kelautan Nasional, 14(3), 155-164.

Bramawanto, R., \& Abida, R. F. (2017). Tinjauan Aspek Klimatologi (ENSO Dan IOD) Dan Dampaknya Terhadap Produksi Garam Indonesia. J. Kelautan Nasional, 12(2), 91-99.

U.S Energy Information Administration. (2006). International energy annual, short term energy outlook. https:/www.eia.gov/outlooks/steo/ [Diakses 22 Mei 2021]

Fernandes, M. S., Brites, G. J. V. N., Costa, J. J., Gaspar, A. R., \& Costa, V. A. F. (2014). Review and future trends of solar adsorption refrigeration systems. J. Renewable and Sustainable Energy Reviews, 39, 102-123.

Hassan, H. Z., \& Mohamad, A. A. (2012). A review on solar-powered closed physisorption cooling systems. J. Renewable and Sustainable Energy Reviews, 16(5): 2516-2538.

Heryati, H., W.S. Pranowo, N.P. Purba, A. Rizal, \& L.P.S. Yuliadi. (2018). Sea surface temperature variability during ENSO Incident (1997-1998 \& 2014-2015) in Java Sea, Indonesia. J. OmniAkuatika, 14(1), 96-107. 
Iskandar, N.B. Sukoco, Kamija, \& W.S. Pranowo. (2018). Karakteristik Termoklin dan Kecepatan Suara di Selat Lombok Berdasarkan Filtering Data CTD Menggunakan Analysis Toolpak. $J$. Chart Datum, (4)1, 43-50.

Junaidi. (2014). Regresi dengan microsoft office excel. Modul Ajar. Fakultas Ekonomi dan Bisnis, Universitas Jambi. https://repository.unja. ac.id/117/1/regresi\%20excel_junaidi2014.pdf. [Diakses 11 April 2021]

Khwee, K. H. (2013). Pengaruh temperatur terhadap kapasitas daya panel surya (studi kasus: Pontianak). Jurnal ELKHA, 5(2), 23-26.

Kumara, N. S. (2010). Pembangkit listrik tenaga surya skala rumah tangga urban dan ketersediaannya di Indonesia. J. Teknologi Elektro, 9(1), 68-75.

Pahlevi, R. (2014). Pengujian karakteristik panel surya berdasarkan intensitas tenaga surya. Naskah Publikasi. Fakultas Teknik, Jurusan Teknik Elektro, Universitas Muhammadiyah Surakarta.

Putra, R. R., Hermon, D., \& Farida, F. (2013). Studi kualitas air payau untuk budidaya perikanan di Kawasan Pesisir Kecamatan Linggo Sari Baganti Kabupaten Pesisir Selatan. J. Mahasiswa Prodi Pendidikan Geografi, 2(1), 1-9.

Sagala, S. L., Bramawanto, R., Kuswardani, A. R. T. D., Pranowo, W. S. (2014). Distribution of Heavy Metals In Natuna Coastal Waters. J. Ilmu \& Teknologi Kelautan Tropis, 6(2), 297-310.

Sarbu, I., \& Adam, M. (2011). Application of solar energy for domestic hot-water and buildings heating/ cooling. Int. J. Energy, 5(2), 34-42.

Sarbu, I., \& Sebarchievici, C. (2013). Review of solar refrigeration and cooling systems. Energy and Building, 67(12), 286-297.

Schlitzer, R. (2020). Ocean Data View 5.3.0. http://odv. awi.de [diakses 2021-06-01]

Siregar, S.N., L.P. Sari, N.P. Purba, W.S. Pranowo, M.L. Syamsuddin.(2017). Pertukaran massa air di Laut Jawa terhadap periodisitas monsun dan Arlindo pada tahun 2015. J. Depik, 6(1), 44-59. and systems: A Manual for Technicians, Trainers and Engineers. ISBN: 978-81-203-4711-3. Chapter 2: 23-24.

Suryana, D., \& Ali, M. M. (2016). Pengaruh temperatur atau suhu terhadap tegangan yang dihasilkan panel surya jenis monokristalin (studi kasus : Baristand Industri Surabaya). Jurnal Teknologi Proses dan Inovasi Industri, 2(1), 49-52.

Solanki, C. S. (2013). Solar photovoltaic technology

Analisis Regresi Temporal Dari Kinerja Mesin Pembuat Es Bertenaga Surya Sebagai Fungsi Dari Radiasi Matahari dan Suhu Udara di Pesisir Lampung Selatan - Putri Wullandari \& Arif Rahman Hakim 
